\title{
SUBSTRATE AND FERTILIZATION IN THE QUALITY OF Myrocarpus frondosus SEEDLINGS
}

\author{
Suelen Carpenedo Aimi ${ }^{*}$, Maristela Machado Araujo ${ }^{2}$, Maria Helena Fermino ${ }^{3}$, Luciane Almeri Tabaldi ${ }^{4}$, \\ Thairini Claudino Zavistanovicz ${ }^{1}$, Patrícia Mieth ${ }^{1}$ \\ ${ }^{1 *}$ Federal University of Santa Maria, Graduate Program in Forest Engineering, Santa Maria, Rio Grande do Sul, Brazil - e-mail: \\ suaimi@gmail.com; thairini.z@gmail.com; patriciamieth@hotmail.com \\ ${ }^{2}$ Federal University of Santa Maria, Departament of Forest Sciences, Santa Maria, Rio Grande do Sul, Brazil - araujo.maristela@ gmail.com \\ ${ }^{3}$ Department of Diagnostic and Agricultural Research - Porto Alegre, Rio Grande do Sul, Brazil - maria-fermino@seapi.rs.gov.br \\ ${ }^{4}$ Federal University of Santa Maria, Departament of Biology, Santa Maria, Rio Grande do Sul, Brazil - lutabaldi@yahoo.com.br
}

Received for publication: 01/06/2018 - Accepted for publication: 05/04/2019

\begin{abstract}
Resumo
Substrato e adubação na qualidade de mudas de Myrocarpus frondosus. Myrocarpus frondosus é uma espécie nativa com alto valor comercial da madeira. Assim, o objetivo dessa pesquisa foi avaliar a qualidade de mudas de Myrocarpus frondosus no viveiro e indicar o substrato e a adubação mais adequados à produção de mudas. Os tratamentos foram quatro combinações de substratos: $\mathrm{S} 1-100 \%$ substrato comercial de turfa do tipo Sphagnum (SC); S2 - 80\% SC e 20\% de casca de arroz carbonizada (CAC); S3 - 60\% SC e 40\% de CAC; S4 $40 \%$ SC e $60 \%$ CAC, e quatro adubações: SA - Sem adubação (testemunha); FLC - fertilizante de liberação controlada; FPL - fertilizante de pronta liberação (sulfato de amônio, superfosfato simples e cloreto de potássio) e FPLF - fertilizante de pronta liberação e micronutrientes do tipo "Fritas". Aos 300 dias após emergência foram avaliadas as variáveis morfológicas e fisiológicas (altura, diâmetro do coleto, área foliar, comprimento radicular, matéria seca aérea e radicular, fluorescência da clorofila $a$ e pigmentos fotossintéticos). Independente do substrato e adubação observou-se crescimento lento da espécie, mesmo para o tratamento onde houve o maior crescimento, o que foi constatado na altura $(17,87 \mathrm{~cm})$ e diâmetro do coleto $(2,62 \mathrm{~mm})$. Recomenda-se o uso do substrato comercial (40\%) com casca de arroz carbonizada (60\%) associado à concentração de $6 \mathrm{~g} \mathrm{~L}$ ${ }^{1}$ de fertilizante de liberação controlada, por apresentarem de maneira geral, efeitos positivos mais marcantes sobre as variáveis morfológicas e fisiológicas no viveiro.

Palavras-chave: Fabaceae, cabreúva, casca de arroz carbonizada, fertilizante de liberação controlada.
\end{abstract}

\begin{abstract}
Myrocarpus frondosus is a native species with high commercial timber value. Thus, the objective of this research was to evaluate the quality of seedlings of Myrocarpus frondosus in the nursery and to indicate the most adequate substrate and fertilization for the production of seedlings. The experiment was conducted in a completely randomized design, with four replications, in a factorial scheme, composed of four combinations of substrates: S1-100\% commercial substrate (CS); S2 - 80\% CS and 20\% carbonated rice husk (CRH); S3 - 60\% CS and 40\% CRH; S4 - 40\% CS and 60\% CRH, and four fertilizations: NF - No fertilization; CRF - controlled release fertilizer (ammonium sulfate, simple superphosphate and potassium chloride); RRF - ready release fertilizer and micronutrients. Physical and chemical analyses were performed on the substrate. At 300 days after emergence, the following morphological variables were evaluated: (height, stem diameter, H/SD ratio, leaf area, root length, aerial dry mass, root dry mass, total dry mass, Dickson quality index) and the physiological variables chlorophyll $a$, chlorophyll $b$, carotenoids, initial fluorescence, maximum fluorescence, $\mathrm{F}_{\mathrm{v}} / \mathrm{F}_{\mathrm{m}}$ ratio and electron transport rate). Regardless of the substrate and fertilization, slow growth of the species was observed, even for the best treatment, which was verified from the height $(17.87 \mathrm{~cm})$ and stem diameter $(2.62 \mathrm{~mm})$. The use of the commercial substrate $(40 \%)$ with carbonated rice husk $(60 \%)$ associated with the concentration of $6 \mathrm{~g} \mathrm{~L}^{-1}$ of controlled release fertilizer is recommended, since they present the best results for the morphological and physiological variables in the nursery in general.

Keywords: Fabaceae, cabreúva, carbonated rice husk, controlled release fertilizer.
\end{abstract}

\section{INTRODUCTION}

Myrocarpus frondosus Allemão (cabreúva) belongs to the Fabaceae family and occurs naturally in Bolivia, Paraguay and Brazil (TROPICOS, 2018), in the Deciduous and Semideciduous Seasonal Forest, being classified as deciduous, early secondary to late secondary, semi-heliophile, tolerating medium intensity shading and low temperatures (CARVALHO, 2003).

It stands out among the native tree species with higher commercial production of wood from the Atlantic Forest biome, due to its high density ( 870 to $1.002 \mathrm{~kg} \mathrm{~m}^{-3}$ ), which gives high durability, even when exposed to the

FLORESTA, Curitiba, PR, v. 49, n. 4, p. 831 - 840, out/dez 2019.

Aimi, S.C. et.al.

ISSN eletrônico 1982-4688

DOI: $10.5380 /$ rf.v49 i4.59748 
environment. It is a meliferous species, used in the perfumery and dyeing industry, having environmental importance, ideal for urban afforestation and recovery of riparian forests (CARVALHO, 2003). The essential oils can be useful in both the pharmaceutical and food industries (SANTI et al., 2017). However, despite their economic and environmental importance, studies on the production and morphological and physiological quality of their seedlings are still needed, focusing on research that optimizes their production in nursery, ensuring higher survival rates and growth in the field.

The function of the substrate is to provide adequate conditions for the growth and development of the plant root system (KÄMPF, 2005). Moreover, according to the same author, it must have good structure, not contract or expand, be free of toxic substances, diseases and pests. The use of secondary components (vermiculite, carbonated rice husk, among others) in the formulation of substrates, added in different proportions, help in the adaptation of the physical and chemical characteristics to a given species, providing better plant development, and shorter production time and final cost of the product. However, such components must be commercially available, inexpensive, and meet the nursery production system.

In the state of Rio Grande do Sul rice production generates rice husk, a byproduct after its processing, which is a renewable waste (PODE, 2016) and can be used in the preparation of the substrate because it provides high aeration space, better ratio air: water, low cost and availability in rice producing regions.

Another fundamental aspect to be observed is the fertilization, which interferes with the functional attributes of plants. According to Gonçalves et al. (2005) there are different types of inorganic fertilizers available for use in nurseries, with differences in raw material, amount of nutrient and release mechanisms. In addition to these, there are organic fertilizers from plant and animal waste (TAIZ; ZEIGER, 2009). However, the fertilization performed in the nurseries, mainly for native species, is still done empirically, using the same nutrients and doses for all plants under cultivation.

In this context, studies to determine techniques that optimize inputs for the production of quality seedlings are needed. The objective of this research was to evaluate the quality of Myrocarpus frondosus seedlings in the nursery and to indicate the most suitable substrate and fertilization for seedling production. Thus, we try to answer the following hypotheses: a) Can the carbonated rice husk be used as a secondary component in the production of Myrocarpus frondosus seedlings in the substrate? b) Are there differences in the morphological and physiological variables of cabreúva plants when using controlled release fertilizers or ready release fertilizers?

\section{MATERIALS AND METHODS}

The research was conducted between May 2014 and March 2015 at the Forest Nursery (29 43 '13' 'S and 53 43' 17' O) of the Federal University of Santa Maria. The Myrocarpus frondosus diaspores were purchased from the State Foundation for Agricultural Research in Santa Maria, RS. The experiment was carried out in a 4x4 factorial scheme (substrate $\mathrm{x}$ fertilization) in a completely randomized design with four replications each, totaling 16 treatments (Table 1). The commercial Sphagnum peat based substrate (SC) was used, which according to the manufacturer, in addition to peat, is composed of expanded vermiculite, agricultural plaster and dolomitic limestone, in which carbonated rice husk (CRH) was added in different proportions ( Table 1).

The fertilization was performed with controlled release fertilizer (CRF), ready release fertilizer (RRF) or the latter plus "Fritted" (Table 1). The CRF used was a Mini Prill in the formulation of 18-05-09 $\left(\mathrm{N}_{-}-\mathrm{P}_{2} \mathrm{O}_{5}-\mathrm{K}_{2} \mathrm{O}\right)$. According to the technical specifications of the manufacturer, when the CRF is placed on a humid substrate with an average temperature of $21^{\circ} \mathrm{C}$, nutrient release occurs gradually, between six and eight months. In the RRF treatments, ammonium sulfate $\left(\left(\mathrm{NH}_{4}\right)_{2} \mathrm{SO}_{4}\right)$, simple superphosphate $\left(\mathrm{P}_{2} \mathrm{O}_{5}\right)$ and potassium chloride $(\mathrm{KCl})$ and $\mathrm{RRF}$ plus "Fritted" (RRFF) were used (Table 1). For RRF and RRFF treatments, topdressing was performed according to what was described by Gonçalves et al. (2005), with a solution prepared by dissolving $200 \mathrm{~g}$ of ammonium sulfate and $150 \mathrm{~g}$ of potassium chloride in $100 \mathrm{~L}$ of water.

Polypropylene tubes with a volume of $180 \mathrm{~cm} 3$ (50.7 mm upper diameter, $13.5 \mathrm{~cm}$ high and eight internal friezes) were used, placed in 54-cell trays. About half a tray was used for each treatment, which represented 24 seedlings. After substrate formulation and fertilizer addition, the containers were filled according to each treatment. To verify the physical and chemical attributes, samples of 2.5 liters of each substrate were sent to the Laboratory of Analysis of Horticultural Substrates of the Federal University of Rio Grande do Sul.

FLORESTA, Curitiba, PR, v. 49, n. 4, p. 831 - 840, out/dez 2019 Aimi, S.C. et.al 
Table 1. Description of the treatments used in the study of Myrocarpus frondosus seedlings.

Tabela 1. Descrição dos tratamentos utilizados no estudo de mudas de Myrocarpus frondosus.

\begin{tabular}{|c|c|}
\hline Substrate & Fertilizing \\
\hline $\begin{array}{l}\text { S1 - } 100 \% \text { comercial substrate } \\
\text { (CS) }\end{array}$ & NF - No Fertilizing (control) \\
\hline $\begin{array}{l}\text { S2 }-80 \% \mathrm{CS} \text { and } 20 \% \text { carbonated } \\
\text { rice husk }(\mathrm{CRH})\end{array}$ & $\begin{array}{l}\text { CRF - controlled release fertilizer, Mini Prill, 18-05-09 }\left(\mathrm{N}_{-} \mathrm{P}_{2} \mathrm{O}_{5}-\mathrm{K}_{2} \mathrm{O}\right) 6 \\
\mathrm{~g} \mathrm{~L}^{-1}\end{array}$ \\
\hline S3 $-60 \%$ CS and $40 \%$ of CRH & $\begin{array}{l}\mathrm{RRF}-150 \mathrm{~g} \text { of ammonium sulfate }\left(\left(\mathrm{NH}_{4}\right)_{2} \mathrm{SO}_{4}\right), 300 \mathrm{~g} \text { of simple } \\
\text { superphosphate }\left(\mathrm{P}_{2} \mathrm{O}_{5}\right) \text { and } 100 \mathrm{~g} \text { of potassium chloride }(\mathrm{KCl}) \text { per m} \mathrm{m}^{3} \text { of } \\
\text { substrate and topdressing.* }\end{array}$ \\
\hline S4 - $40 \% \mathrm{CS}$ and $60 \% \mathrm{CRH}$ & $\begin{array}{l}\mathrm{RRFF}-150 \mathrm{~g}\left(\mathrm{NH}_{4}\right)_{2} \mathrm{SO}_{4}, 300 \mathrm{~g} \text { of } \mathrm{P}_{2} \mathrm{O}_{5}, 100 \mathrm{~g} \text { of } \mathrm{KCl} \text { added of "Fritted" } \\
\text { fertilizer - } 150 \mathrm{~g} \text { of FTE BR12 micronutrients containing } 3 \% \text { Sulfur, } \\
1.8 \% \text { of Boron, } 0.8 \% \text { of Copper, } 2.0 \% \text { of Manganese, } 0.1 \% \text { of } \\
\text { Molybdenum, } 3.0 \% \text { of Iron and } 9 \% \text { of Zinc per } \mathrm{m}^{3} \text { of substrate and } \\
\text { topdressing.* }\end{array}$ \\
\hline
\end{tabular}

*Recommendation of Gonçalves et al. (2005).

Two diaspores were seeded on each tube, which were covered with a thin layer of the substrate, and the trays were taken to the greenhouse, with irrigation by mobile bar containing micro-sprinklers (flow rate $8 \mathrm{~mm}$ day ) with four daily irrigations. The thinning was done at 40 days after sowing, eliminating the surplus seedlings, leaving only one per container. At 120 days after sowing, the trays were removed from the greenhouse and taken to an area covered with shading screen (50\%), with daily irrigation maintained until the final evaluations. At 40 days after emergence, top dressing was performed in the RRF and RRFF treatments every ten days until the end of the experiment, with the presence and absence of $\mathrm{KCl}$ in the solution being intercalated with $1 \mathrm{~L}$ of the solution per tray in the early hours of the morning, followed by light irrigation.

Emergence was evaluated at 30 days after sowing, and morphological and physiological parameters were measured at 300 days after emergence. Height (H), and stem diameter (SD) were measured with a ruler and with a digital caliper respectively, thus obtaining the $\mathrm{H} / \mathrm{SD}$ ratio of eight central plants. Leaf area and total root length were determined in four seedlings per treatment, so the roots were sieved, and then together with the leaves of the plants were placed on A4 white paper, then pressed by transparent glass and photographed with a digital camera, supported by a structure with a fixed height of $0.18 \mathrm{~m}$ and $1.4 \mathrm{zoom}$. The images were processed in the ImageJ software (National Institutes of Health, Bethesda, MD, USA), obtaining the leaf area and root length. To quantify the aerial and root dry matter, the same samples were used, which were placed in paper packages, identified and taken to a greenhouse with forced air circulation at $65^{\circ} \mathrm{C}$, for 72 hours and weighed on an analytical balance to obtain the aerial dry matter (ADM), root dry matter (RDM), total dry matter (TDM) and the Dickson's Quality Index was calculated according to Dickson et al. (1960).

Chlorophyll $a$ fluorescence was evaluated using a portable fluorometer (Junior-Pam Chlorophyll Fluorometer Walz) on fully expanded leaves of four seedlings per treatment, totaling 16 plants. The leaves selected were acclimated for 30 minutes in the dark with aluminum foil. Then, they were exposed to pulses of saturated light with wavelength induced by red light (peak at $650 \mathrm{~nm}$ ), obtaining the attributes of initial fluorescence $\left(\mathrm{F}_{\mathrm{o}}\right)$, maximum fluorescence $\left(\mathrm{F}_{\mathrm{m}}\right)$, maximum photochemical efficiency of photosystem II $\left(\mathrm{F}_{\mathrm{v}} / \mathrm{F}_{\mathrm{m}}\right)$ and maximum electron transport rate (ETR). The physiological attributes, contents of chlorophyll $a, b$ and carotenoids were analyzed at the Plant Physiology Laboratory, belonging to the Department of Biology (UFSM). For these analyzes, the fourth expanded leaf from three plants per treatment was collected, immediately frozen in liquid nitrogen and then stored in a freezer at $-80^{\circ} \mathrm{C}$ until quantification.

Chlorophyll $a$, chlorophyll $b$ and carotenoids were determined according to Hiscox and Israelstam (1979). Fresh leaf samples $(0.05 \mathrm{~g})$ were incubated for two hours at $65{ }^{\circ} \mathrm{C}$ with dimethyl sulfoxide (DMSO). The absorbances of the solution were measured on a SF325NM spectrophotometer (Bel Engineering, Italy) at $663 \mathrm{~nm}$ for chlorophyll $a, 645 \mathrm{~nm}$ for chlorophyll $b$ and $470 \mathrm{~nm}$ for carotenoids, and estimated by the Lichtenthaler equation (1987).

The data were verified for the assumptions of normality of error distribution by the Shapiro-Wilk test and homogeneity of variances by the Bartlett test. Subsequently, the analysis of variance and comparison of means at $5 \%$ probability of error were performed by Tukey test, with the software Sisvar (version 5.6) (FERREIRA, 2014).

FLORESTA, Curitiba, PR, v. 49, n. 4, p. 831 - 840, out/dez 2019.

Aimi, S.C. et.al.

ISSN eletrônico 1982-4688

DOI: $10.5380 /$ rf.v49 i 4.59748 


\section{RESULTS}

It was found that, for physical characteristics, the values of wet density increased from 356.04 to 424.32 $\mathrm{kg} \mathrm{m}^{-3}$ (S1 to S3) as the proportion of carbonated rice husk increased $(0.20$ and $40 \%)$, decreasing in the substrate with higher proportion of this component $\left(\mathrm{S} 4: 295.96 \mathrm{~kg} \mathrm{~m}^{-3}\right.$ ). The dry density was higher for substrate $\mathrm{S} 1$ (commercial) and lower for S4, and the converse for the aeration space. The total porosity had higher values for S3 and S2 (90.57 and 88.73\%, respectively), being lower in the commercial substrate (S1). However, for readily available water the highest value observed was in S1 and the lowest in S3 (Table 2). For the chemical variables, the $\mathrm{pH}$ was in the appropriate range (5.5-6.5), with $\mathrm{S} 4$ having the highest value and S2 the lowest. For electrical conductivity, the highest mean $\left(0.51 \mathrm{mS} \mathrm{cm}^{-1}\right)$ was observed in the commercial substrate (S1), and the lowest value in the $60 \% \mathrm{CRH}$ treatment.

Table 2. Means of wet density (WD), dry density (DD), total porosity (TP), aeration space (AS), readily available water (RAW), buffer water (BW), remaining water (RW), $\mathrm{pH}$ and electrical conductivity (EC) of substrate in combinations with carbonated rice husk used in the production of Myrocarpus frondosus seedlings, Santa Maria, RS.

Tabela 2. Médias de densidade úmida (DU), densidade seca (DS), porosidade total (PT), espaço de aeração (EA), água facilmente disponível (AFD), água tamponante (AT), água remanescente (AR), $\mathrm{pH}$ e condutividade elétrica (CE) de substrato em combinações com casca de arroz carbonizada utilizados na produção de mudas de Myrocarpus frondosus, Santa Maria, RS.

\begin{tabular}{|c|c|c|c|c|c|c|c|c|c|}
\hline \multirow{2}{*}{ Substrates } & WD & DD & TP & AS & RAW & BW & $\mathbf{R W}$ & pH & \multirow{2}{*}{$\begin{array}{c}\mathbf{E C} \\
\mathrm{mS} \\
\mathrm{cm}^{-1}\end{array}$} \\
\hline & \multicolumn{2}{|c|}{$\mathrm{kg} \mathrm{m}^{-3}$} & \multicolumn{6}{|c|}{ 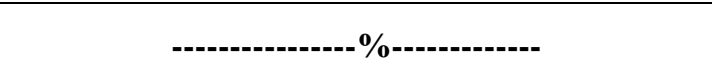 } & \\
\hline S1-100\%CS & 356.04 & 171.59 & 82.74 & 28.54 & 17.24 & 3.90 & 33.05 & 5.81 & 0.51 \\
\hline $\mathrm{S} 2-80 \% \mathrm{CS}+20 \% \mathrm{CRH}$ & 389.55 & 169.94 & 88.73 & 40.96 & 16.56 & 3.76 & 27.45 & 5.76 & 0.41 \\
\hline $\mathrm{S} 3-60 \% \mathrm{CS}+40 \% \mathrm{CRH}$ & 424.32 & 156.46 & 90.57 & 46.48 & 14.53 & 3.43 & 26.13 & 5.89 & 0.36 \\
\hline $\mathrm{S} 4-40 \% \mathrm{CS}+60 \% \mathrm{CRH}$ & 295.96 & 156.44 & 84.67 & 46.58 & 15.04 & 2.59 & 20.47 & 5.96 & 0.28 \\
\hline
\end{tabular}

CS - Commercial substrate and CRH - carbonated rice husk.

The emergence of the diaspores of Myrocarpus frondosus occurred on the 25th day after sowing and ended on the 40th day. In the analysis of variance there was an interaction $(p<0.05)$ between the factors (substrate $\mathrm{x}$ fertilization) for height (H), leaf area (LA), root length (RL), aerial dry matter (ADM), root dry matter (RDM), total dry matter (TDM), Dickson quality index (DQI), chlorophyll $a$, chlorophyll $b$, carotenoids, initial fluorescence $\left(F_{o}\right)$ and $F_{v} / F_{m}$ ratio. For the stem diameter $(S D), H / S D$ ratio and maximum fluorescence (Fm) there was a significant effect $(p<0.05)$ on the isolated factors. However, there was no significant effect on the electron transport rate (ETR). For the attributes H, ADM, RDM, TDM and DQI the highest means were observed in the treatment S4 (40\% CS and 60\% CRH) and fertilization with CRF (Table 3). However, for the LA attribute the highest values were in substrates S3 and S4, and for RL in substrates S2 and S4. For both attributes the highest means were with the use of CRF.

Table 3. Effect of substrates and fertilizations on the height, leaf area, aerial dry matter, root length, root dry matter, total dry matter and Dickson quality index of Myrocarpus frondosus seedlings at 300 days in nursery.

Tabela 3. Efeito dos substratos e adubações na altura, área foliar, matéria seca aérea, comprimento radicular, matéria seca radicular, matéria seca total e índice de qualidade de Dickson de mudas de Myrocarpus frondosus, aos 300 dias em viveiro. 


\begin{tabular}{|c|c|c|c|c|c|}
\hline \multirow{2}{*}{ Characteristics } & \multirow{2}{*}{ Substrates } & \multicolumn{4}{|c|}{ Fertilization } \\
\hline & & NF & CRF & RRF & RRFF \\
\hline \multirow{4}{*}{$\begin{array}{l}\text { Height } \\
(\mathrm{cm})\end{array}$} & S1-100\% CS & $4.15 \mathrm{Ca}^{*}$ & 13.07 Ac & $5.75 \mathrm{Ba}$ & $5.68 \mathrm{Ba}$ \\
\hline & $\mathrm{S} 2-80 \% \mathrm{CS}+20 \% \mathrm{CRH}$ & $3.92 \mathrm{Ca}$ & $13.29 \mathrm{Ac}$ & $6.25 \mathrm{Ba}$ & $5.42 \mathrm{Ba}$ \\
\hline & $\mathrm{S} 3-60 \% \mathrm{CS}+40 \% \mathrm{CRH}$ & $3.56 \mathrm{Ca}$ & $16.42 \mathrm{Ab}$ & $5.81 \mathrm{Ba}$ & $6.39 \mathrm{Ba}$ \\
\hline & $\mathrm{S} 4-40 \% \mathrm{CS}+60 \% \mathrm{CRH}$ & $4.50 \mathrm{Ca}$ & $17.87 \mathrm{Aa}$ & $6.87 \mathrm{Ba}$ & $6.58 \mathrm{Ba}$ \\
\hline $\mathrm{CV}(\%)$ & & \multicolumn{4}{|c|}{10.74} \\
\hline \multirow{4}{*}{$\begin{array}{l}\text { Leaf Area } \\
\quad\left(\mathrm{cm}^{2}\right)\end{array}$} & $\mathrm{S} 1-100 \% \mathrm{CS}$ & $5.17 \mathrm{Cb}$ & $110.03 \mathrm{Ab}$ & $14.96 \mathrm{Bb}$ & $18.11 \mathrm{Ba}$ \\
\hline & $\mathrm{S} 2-80 \% \mathrm{CS}+20 \% \mathrm{CRH}$ & $5.89 \mathrm{Cb}$ & $105.51 \mathrm{Ab}$ & $23.34 \mathrm{Bb}$ & $18.47 \mathrm{Ba}$ \\
\hline & S3-60\% CS+40\% CRH & $6.55 \mathrm{Cb}$ & 164.17 Aa & $24.54 \mathrm{Bb}$ & $26.42 \mathrm{Ba}$ \\
\hline & $\mathrm{S} 4-40 \% \mathrm{CS}+60 \% \mathrm{CRH}$ & $11.47 \mathrm{Ca}$ & $196.60 \mathrm{Aa}$ & $52.85 \mathrm{Ba}$ & $34.89 \mathrm{Ba}$ \\
\hline $\mathrm{CV}(\%)$ & & \multicolumn{4}{|c|}{12.11} \\
\hline \multirow{4}{*}{$\begin{array}{l}\text { Aerial Dry } \\
\text { Matter } \\
(\mathrm{g})\end{array}$} & S1-100\% CS & $0.067 \mathrm{Cb}$ & $1.511 \mathrm{Ab}$ & $0.184 \mathrm{Ba}$ & $0.973 \mathrm{Aa}$ \\
\hline & $\mathrm{S} 2-80 \% \mathrm{CS}+20 \% \mathrm{CRH}$ & $0.069 \mathrm{Cb}$ & $1.514 \mathrm{Ab}$ & $0.284 \mathrm{Ba}$ & $0.168 \mathrm{Bb}$ \\
\hline & $\mathrm{S} 3-60 \% \mathrm{CS}+40 \% \mathrm{CRH}$ & $0.071 \mathrm{Cb}$ & $1.996 \mathrm{Ab}$ & $0.272 \mathrm{Ba}$ & $0.257 \mathrm{Bb}$ \\
\hline & $\mathrm{S} 4-40 \% \mathrm{CS}+60 \% \mathrm{CRH}$ & $0.109 \mathrm{Ca}$ & $2.864 \mathrm{Aa}$ & $0.516 \mathrm{Ba}$ & $0.358 \mathrm{Bb}$ \\
\hline $\mathrm{CV}(\%)$ & & \multicolumn{4}{|c|}{44.21} \\
\hline \multirow{4}{*}{$\begin{array}{l}\text { Root Legth } \\
\text { (m) }\end{array}$} & $\mathrm{S} 1-100 \% \mathrm{CS}$ & $9.80 \mathrm{Aa}$ & $12.80 \mathrm{Ab}$ & $10.71 \mathrm{Ab}$ & $7.29 \mathrm{Ab}$ \\
\hline & $\mathrm{S} 2-80 \% \mathrm{CS}+20 \% \mathrm{CRH}$ & $9.75 \mathrm{Ba}$ & $16.51 \mathrm{Aa}$ & $9.08 \mathrm{Bb}$ & $11.86 \mathrm{Ba}$ \\
\hline & $\mathrm{S} 3-60 \% \mathrm{CS}+40 \% \mathrm{CRH}$ & $9.00 \mathrm{Aa}$ & $12.96 \mathrm{Ab}$ & $8.70 \mathrm{Ab}$ & $8.44 \mathrm{Ab}$ \\
\hline & $\mathrm{S} 4-40 \% \mathrm{CS}+60 \% \mathrm{CRH}$ & $9.94 \mathrm{Ba}$ & $23.40 \mathrm{Aa}$ & $18.26 \mathrm{Aa}$ & $14.61 \mathrm{Ba}$ \\
\hline $\mathrm{CV}(\%)$ & & \multicolumn{4}{|c|}{33.14} \\
\hline \multirow{4}{*}{$\begin{array}{l}\text { Root Dry } \\
\text { Matter } \\
\text { (g) }\end{array}$} & $\mathrm{S} 1-100 \% \mathrm{CS}$ & $0.0697 \mathrm{Ba}$ & $1.2390 \mathrm{Ac}$ & $0.1597 \mathrm{Ba}$ & $0.1422 \mathrm{Bb}$ \\
\hline & $\mathrm{S} 2-80 \% \mathrm{CS}+20 \% \mathrm{CRH}$ & $0.0465 \mathrm{Ba}$ & $1.3162 \mathrm{Ac}$ & $0.3067 \mathrm{Ba}$ & $0.1415 \mathrm{Bb}$ \\
\hline & $\mathrm{S} 3-60 \% \mathrm{CS}+40 \% \mathrm{CRH}$ & $0.0710 \mathrm{Ba}$ & $1.9702 \mathrm{Ab}$ & $0.2765 \mathrm{Ba}$ & $0.2027 \mathrm{Bb}$ \\
\hline & $\mathrm{S} 4-40 \% \mathrm{CS}+60 \% \mathrm{CRH}$ & $0.0920 \mathrm{Ca}$ & $2.5582 \mathrm{Aa}$ & $0.4102 \mathrm{Ba}$ & $0.4285 \mathrm{Ba}$ \\
\hline $\mathrm{CV}(\%)$ & & \multicolumn{4}{|c|}{33.14} \\
\hline \multirow{4}{*}{$\begin{array}{l}\text { Total Dry } \\
\text { Matter } \\
(\mathrm{g})\end{array}$} & S1-100\% CS & $0.1372 \mathrm{Ca}$ & $2.7500 \mathrm{Ac}$ & $0.3437 \mathrm{Ca}$ & $1.1157 \mathrm{Ba}$ \\
\hline & $\mathrm{S} 2-80 \% \mathrm{CS}+20 \% \mathrm{CRH}$ & $0.1157 \mathrm{Ba}$ & $2.8305 \mathrm{Ac}$ & $0.5905 \mathrm{Ba}$ & $0.3095 \mathrm{Ba}$ \\
\hline & $\mathrm{S} 3-60 \% \mathrm{CS}+40 \% \mathrm{CRH}$ & $0.1417 \mathrm{Ba}$ & $3.9665 \mathrm{Ab}$ & $0.5482 \mathrm{Ba}$ & $0.4602 \mathrm{Ba}$ \\
\hline & $\mathrm{S} 4-40 \% \mathrm{CS}+60 \% \mathrm{CRH}$ & $0.2015 \mathrm{Ba}$ & $5.4222 \mathrm{Aa}$ & $0.9267 \mathrm{Ba}$ & $07862 \mathrm{Ba}$ \\
\hline $\mathrm{CV}(\%)$ & & \multicolumn{4}{|c|}{38.78} \\
\hline \multirow{4}{*}{ DQI } & S1-100\% CS & $0.035 \mathrm{Ba}^{*}$ & $0.571 \mathrm{Ac}$ & $0.079 \mathrm{Ba}$ & $0.098 \mathrm{Bb}$ \\
\hline & $\mathrm{S} 2-80 \% \mathrm{CS}+20 \% \mathrm{CRH}$ & $0.026 \mathrm{Ca}$ & $0.585 \mathrm{Ac}$ & $0.147 \mathrm{Ba}$ & $0.072 \mathrm{Cb}$ \\
\hline & $\mathrm{S} 3-60 \% \mathrm{CS}+40 \% \mathrm{CRH}$ & $0.030 \mathrm{Ba}$ & $0.765 \mathrm{Ab}$ & $0.144 \mathrm{Ba}$ & $0.100 \mathrm{Bb}$ \\
\hline & $\mathrm{S} 4-40 \% \mathrm{CS}+60 \% \mathrm{CRH}$ & $0.049 \mathrm{Da}$ & $1.047 \mathrm{Aa}$ & $0.216 \mathrm{Ba}$ & $0.197 \mathrm{Ca}$ \\
\hline $\mathrm{CV}(\%)$ & & \multicolumn{4}{|c|}{25.26} \\
\hline
\end{tabular}

*Averages not followed by the same uppercase letter (row) and lowercase letter (column) differ by Tukey test ( $p<0.05$ ). Being: CS Commercial Substrate; CRH - Carbonated rice husk; NF - No fertilizing; CRF - Controlled release fertilizer; RRF - Ready Release Fertilizer; RRFF- RRF and "Fritted" fertilizer; and CV: Coefficient of variation.

For initial fluorescence $\left(\mathrm{F}_{\mathrm{o}}\right)$ there was a difference in substrates $\mathrm{S} 1$ and $\mathrm{S} 4$ in the fertilization with RRFF, with lower value in substrate S1 in the fertilization with CRF (Table 4). The photochemical efficiency of photosystem II $\left(\mathrm{F}_{\mathrm{v}} / \mathrm{F}_{\mathrm{m}}\right)$ showed the highest mean in S3 (0.72) in the fertilization with CRF and the lowest mean in substrate S2 in the fertilization with RRFF. Regarding chlorophyll $a$ content, the highest mean was observed in substrate S4, differing from substrates S3 and S2, in the fertilization with RRF, and the lowest content was in the same fertilization, but in substrate S2 (Table 4).

For chlorophyll $b$, the highest mean was observed in substrate $\mathrm{S} 4\left(0.611 \mathrm{mg} \mathrm{g} \mathrm{MF}^{-1}\right)$ in the fertilization with RRF and the lowest mean in S2. However, for carotenoids a different behavior was observed, in which the highest mean was for substrate $\mathrm{S} 2$ in the fertilization with RRFF and the lowest in the same substrate, but without fertilization. 
Table 4. Different substrates and fertilizations in the initial fluorescence, maximum quantum yield PSII, chlorophyll $a, b$ and carotenoids of Myrocarpus frondosus seedlings at 300 days in nursery.

Tabela 4. Diferentes substratos e adubações na fluorescência inicial, rendimento quântico máximo PSII, clorofila $a, b$ e carotenoides de mudas de Myrocarpus frondosus, aos 300 dias em viveiro.

\begin{tabular}{|c|c|c|c|c|c|}
\hline \multirow{2}{*}{ Characteristics } & \multirow{2}{*}{ Substrates } & \multicolumn{4}{|c|}{ Fertilization } \\
\hline & & NF & CRF & RRF & RRFF \\
\hline \multirow{4}{*}{$\begin{array}{c}\text { Initial } \\
\text { Fluorescence } \\
\left(\mathrm{F}_{\mathrm{o}}\right)\end{array}$} & S1-100\% CS & $296.50 \mathrm{Ab}$ & $288.5 \mathrm{Ab}$ & $523.5 \mathrm{Bb}$ & $500.0 \mathrm{Bb}$ \\
\hline & $\mathrm{S} 2-80 \% \mathrm{CS}+20 \% \mathrm{CRH}$ & $444.50 \mathrm{Ab}$ & $352.5 \mathrm{Ab}$ & $277.5 \mathrm{Ac}$ & $794.0 \mathrm{Ba}$ \\
\hline & $\mathrm{S} 3-60 \% \mathrm{CS}+40 \% \mathrm{CRH}$ & $338.00 \mathrm{Ab}$ & $434.0 \mathrm{Aa}$ & $810.5 \mathrm{Ba}$ & $506.5 \mathrm{Ab}$ \\
\hline & $\mathrm{S} 4-40 \% \mathrm{CS}+60 \% \mathrm{CRH}$ & $816.00 \mathrm{Aa}$ & $549.5 \mathrm{Aa}$ & $730.5 \mathrm{Aa}$ & $883.5 \mathrm{Aa}$ \\
\hline $\mathrm{CV}(\%)$ & & \multicolumn{4}{|c|}{21.29} \\
\hline \multirow{4}{*}{$\mathrm{F}_{\mathrm{v}} / \mathrm{F}_{\mathrm{m}}$} & S1-100\% CS & $0.30 \mathrm{Ba}$ & $0.69 \mathrm{Aa}$ & $0.57 \mathrm{Aa}$ & $0.44 \mathrm{Ba}$ \\
\hline & $\mathrm{S} 2-80 \% \mathrm{CS}+20 \% \mathrm{CRH}$ & $0.39 \mathrm{Ba}$ & $0.56 \mathrm{Ab}$ & $0.55 \mathrm{Aa}$ & $0.22 \mathrm{Bb}$ \\
\hline & $\mathrm{S} 3-60 \% \mathrm{CS}+40 \% \mathrm{CRH}$ & $0.55 \mathrm{Aa}$ & $0.72 \mathrm{Aa}$ & $0.46 \mathrm{Aa}$ & $0.57 \mathrm{Aa}$ \\
\hline & $\mathrm{S} 4-40 \% \mathrm{CS}+60 \% \mathrm{CRH}$ & $0.41 \mathrm{Aa}$ & $0.44 \mathrm{Ab}$ & $0.69 \mathrm{Bb}$ & $0.51 \mathrm{Aa}$ \\
\hline $\mathrm{CV}(\%)$ & & \multicolumn{4}{|c|}{20.28} \\
\hline \multirow{4}{*}{$\begin{array}{l}\text { Chlorophyll } a \\
\left(\mathrm{mg} \mathrm{g} \mathrm{MF}^{-1}\right)\end{array}$} & S1-100\% CS & $0.680 \mathrm{Aa}$ & $0.892 \mathrm{Aa}$ & $0.974 \mathrm{Aa}$ & $0.622 \mathrm{Aa}$ \\
\hline & $\mathrm{S} 2-80 \% \mathrm{CS}+20 \% \mathrm{CRH}$ & $0.636 \mathrm{Aa}$ & $0.499 \mathrm{Bb}$ & $0.435 \mathrm{Bb}$ & $0.957 \mathrm{Aa}$ \\
\hline & $\mathrm{S} 3-60 \% \mathrm{CS}+40 \% \mathrm{CRH}$ & $0.652 \mathrm{Aa}$ & $0.915 \mathrm{Aa}$ & $0.653 \mathrm{Ab}$ & $0.545 \mathrm{Aa}$ \\
\hline & $\mathrm{S} 4-40 \% \mathrm{CS}+60 \% \mathrm{CRH}$ & $0.767 \mathrm{Aa}$ & $0.673 \mathrm{Ab}$ & $1.005 \mathrm{Aa}$ & $0.681 \mathrm{Aa}$ \\
\hline $\mathrm{CV}(\%)$ & & \multicolumn{4}{|c|}{35.08} \\
\hline \multirow{4}{*}{$\begin{array}{l}\text { Chlorophyll } b \\
\left(\mathrm{mg} \mathrm{g} \mathrm{MF}^{-1}\right)\end{array}$} & S1-100\% CS & $0.429 \mathrm{Aa}$ & $0.585 \mathrm{Aa}$ & $0.605 \mathrm{Aa}$ & $0.436 \mathrm{Aa}$ \\
\hline & $\mathrm{S} 2-80 \% \mathrm{CS}+20 \% \mathrm{CRH}$ & $0.405 \mathrm{Ba}$ & $0.304 \mathrm{Ba}$ & $0.269 \mathrm{Bb}$ & $0.601 \mathrm{Aa}$ \\
\hline & $\mathrm{S} 3-60 \% \mathrm{CS}+40 \% \mathrm{CRH}$ & $0.433 \mathrm{Aa}$ & $0.554 \mathrm{Aa}$ & $0.426 \mathrm{Ab}$ & $0.385 \mathrm{Aa}$ \\
\hline & $\mathrm{S} 4-40 \% \mathrm{CS}+60 \% \mathrm{CRH}$ & $0.484 \mathrm{Aa}$ & $0.412 \mathrm{Aa}$ & $0.611 \mathrm{Aa}$ & $0.415 \mathrm{Aa}$ \\
\hline $\mathrm{CV}(\%)$ & & \multicolumn{4}{|c|}{37.92} \\
\hline \multirow{4}{*}{$\begin{array}{l}\text { Carotenoids } \\
\left(\mathrm{mg} \mathrm{g} \mathrm{MF}^{-1}\right)\end{array}$} & S1-100\% CS & $0.315 \mathrm{Aa}$ & $0.416 \mathrm{Aa}$ & $0.420 \mathrm{Aa}$ & $0.261 \mathrm{Ab}$ \\
\hline & $\mathrm{S} 2-80 \% \mathrm{CS}+20 \% \mathrm{CRH}$ & $0.120 \mathrm{Bb}$ & $0.239 \mathrm{Ba}$ & $0.217 \mathrm{Bb}$ & $0.445 \mathrm{Aa}$ \\
\hline & $\mathrm{S} 3-60 \% \mathrm{CS}+40 \% \mathrm{CRH}$ & $0.276 \mathrm{Aa}$ & $0.373 \mathrm{Aa}$ & $0.300 \mathrm{Ab}$ & $0.230 \mathrm{Ab}$ \\
\hline & $\mathrm{S} 4-40 \% \mathrm{CS}+60 \% \mathrm{CRH}$ & $0.339 \mathrm{Aa}$ & $0.320 \mathrm{Aa}$ & $0.441 \mathrm{Aa}$ & $0.306 \mathrm{Ab}$ \\
\hline
\end{tabular}

$\mathrm{CV}(\%)$ 33.69

** Averages not followed by the same uppercase letter (row) and lowercase letter (column) differ by Tukey test ( $p<0.05$ ). Being: CS Commercial Substrate; CRH - Carbonated rice husk; NF - No fertilizing; CRF - Controlled release fertilizer; RRF - Ready Release Fertilizer; RRFF- RRF and "Fritted" fertilizer; and CV: Coefficient of variation.

The highest mean observed for the stem diameter (SD) was in S4, differing from the other treatments. Regarding fertilization, the highest value was found for fertilization with CRF, also differing from the other treatments (Table 5). 
Table 5. Means of stem diameter (SD), H/SD ratio, maximum fluorescence $\left(\mathrm{F}_{\mathrm{m}}\right)$ and electron transport rate (ETR) of Myrocarpus frondosus seedlings at 300 days in nursery.

Tabela 5. Médias de diâmetro do coleto (DC), relação H/DC, fluorescência máxima $\left(\mathrm{F}_{\mathrm{m}}\right)$ e taxa de transporte de elétrons (ETR) de mudas de Myrocarpus frondosus, aos 300 dias em viveiro.

\begin{tabular}{|c|c|c|c|c|}
\hline Substrate & $\mathrm{SD}(\mathbf{m m})$ & H/SD & $\mathbf{F}_{\mathbf{m}}$ & $\operatorname{ETR}\left(\mu \mathrm{mol} \mathrm{m} \mathrm{m}^{-2} \mathrm{~s}^{-1}\right)$ \\
\hline S1-100\% CS & $2.18 b^{*}$ & $3.24^{\mathrm{ns}}$ & $915.87 b^{*}$ & $30.69^{\mathrm{ns}}$ \\
\hline $\mathrm{S} 2-80 \% \mathrm{CS}+20 \% \mathrm{CRH}$ & $2.23 \mathrm{~b}$ & 3.14 & $824.75 \mathrm{~b}$ & 31.37 \\
\hline S3-60\% CS+40\% CRH & $2.34 \mathrm{~b}$ & 3.22 & $1.270 .37 \mathrm{a}$ & 29.86 \\
\hline $\mathrm{S} 4-40 \% \mathrm{CS}+60 \% \mathrm{CRH}$ & $2.62 \mathrm{a}$ & 3.27 & $1.257 .87 \mathrm{a}$ & 38.62 \\
\hline Fertilization & SD $(\mathbf{m m})$ & H/SD & $\mathbf{F}_{\mathbf{m}}$ & $\operatorname{ETR}\left(\mu \mathrm{mol} \mathrm{m} \mathrm{m}^{-2} \mathrm{~s}^{-1}\right)$ \\
\hline $\mathrm{NF}$ & $1.44 c^{*}$ & $2.81 \mathrm{c}^{*}$ & $859.25^{\mathrm{ns}}$ & $29.62^{\mathrm{ns}}$ \\
\hline $\mathrm{CRF}$ & $3.96 \mathrm{a}$ & $3.87 \mathrm{a}$ & 1059.50 & 27.29 \\
\hline RRF & $2.06 \mathrm{~b}$ & $3.03 \mathrm{~b}$ & 1.110 .50 & 40.60 \\
\hline RRFF & $1.92 \mathrm{~b}$ & $3.17 \mathrm{~b}$ & 1.239 .62 & 33.03 \\
\hline $\mathrm{CV}(\%)$ & 10.69 & 9.05 & 32.36 & 23.61 \\
\hline
\end{tabular}

*Averages not followed by the same letter differ from each other by Tukey test. $(p<0.05)$. Being: CS - Commercial substrate; CRH - carbonated rice husk; NF - no fertilization; CRF - controlled release fertilizer; RRF- ready release fertilizer; RRFF- RRF and "Fritted" fertilizer; and CV: Coefficient of variation and ns - não significativo.

However, for the H/SD ratio, there was no significant effect $(p<0.05)$ for the substrate, only for fertilization, and the highest mean was also for the fertilization with CRF (Table 5). The maximum fluorescence $\left(F_{m}\right)$ presented higher mean in S3, not differing from substrate S4.

\section{DISCUSSION}

Dry density (DD) presented values (Table 2) below the recommended by Bunt (1974) (between 400 and $500 \mathrm{~g} \mathrm{~g} \mathrm{~L}^{-1}$ ), and is still considered as a reference today. However, in the current market there are different containers used for plant production, and Kämpf (2005) recommends using substrates with dry density from 100 to $300 \mathrm{~g} \mathrm{~L}^{-1}$ for multi-cell trays, from 200 to $400 \mathrm{~g} \mathrm{~L}^{-1}$ for pots up to $15 \mathrm{~cm}$ high, 300 to $500 \mathrm{~g} \mathrm{~L}^{-1}$ for pots of 20 to $30 \mathrm{~cm}$ high, and 500 to $800 \mathrm{~g} \mathrm{~L}^{-1}$ for pots larger than $30 \mathrm{~cm}$ high. The higher the density, the more expensive the cultivation in containers will be, due to limitations in the development of the seedlings and difficulty in their transport (KÄMPF, 2005). In the substrate DD is a feature inversely related to porosity. Thus, as density increases above the recommended range, a restriction to root growth occurs.

All samples presented high values of total porosity (TP) (Table 2). According to Kämpf (2005), the TP of substrates should be within an ideal range ( $75 \%$ to $90 \%$ ), which generally presents better aeration, water availability and drainage capacity. This physical characteristic is important because the substrate must be porous, thus allowing gas exchange, avoiding the lack of oxygen (KRATZ et al., 2013) and water availability (water:air ratio) to the roots.

Most substrates presented aeration space (AE) greater than 30\% (Table 2), ranging from 28.54 to $46.58 \%$. De Boodt and Verdonck (1972) recommend that the ideal range should vary from $20 \%$ to $30 \%$, which was met by the commercial substrate (S1). Schmitz et al. (2002) also suggest an ideal AE of 30\%, however, in all substrates with the addition of $\mathrm{CRH}$ this value was higher. The aeration of the substrate depends on the amount and size of the particles. Thus, for substrates S2, S3 and S4 the high AE may be associated with the uniformity and size of $\mathrm{CRH}$, favoring macropore formation. The mean of readily available water (RAW) was below that recommended by Schmitz et al. (2002), which should be 24 to $40 \%$, taking into account the fact that the mixtures with CRH decreased this content (Table 2) below the limit, which indicates the need for higher frequency and smaller volume per irrigation. However, the values were probably not limiting because the species has no preference for a watersaturated environment (Table 2).

Regarding the chemical characteristics, the $\mathrm{pH}$ was in the appropriate range for all substrates, which indicates good availability of nutrients in these substrates. In the electrical conductivity the highest mean $(0.51 \mathrm{mS}$

FLORESTA, Curitiba, PR, v. 49, n. 4, p. 831 - 840, out/dez 2019.

Aimi, S.C. et.al.

ISSN eletrônico 1982-4688

DOI: $10.5380 /$ rf.v49 i4.59748 
$\mathrm{cm}^{-1}$ ) was for the commercial substrate (S1), decreasing with the addition of CRH (Table 2). This lower electrical conductivity of CRH is probably due to the fact that this material is low in nutrients. According to Kämpf (2005), EC is a parameter that informs substrate salinity, and ideal values vary among species, cultivars and clones. According to the same author, for forest species, the EC should be generally between 1.5 and $3.0 \mathrm{mS} \mathrm{cm}^{-1}$. The results found for this substrate are below this range. However, lower values are less harmful compared to very high EC, and under the fertilization with CRF, RRF and RRFF, there was an increase of EC, favoring growth, because in the commercial substrates fertilizers are not usually added in order to give the nursery farmers greater autonomy to choose the fertilizer to be used.

For the morphological and physiological variables of the plants of Myrocarpus frondosus (H, SD, LA, RL, ADM, RDM, TDM and DQI), the highest means were observed with substrate S4 (40\% CS + 60\% CRH) and in the fertilization with controlled release fertilizer (CRF) (Table 3). The substrate with larger aeration space and low readily available water was responsible for the highest growth, which can be explained by the natural occurrence of the species associated with watercourses. In these places, the soils are usually sandy, allowing more drainage.

The CRH has desirable physical and chemical characteristics such as low density and salinity, slightly alkaline $\mathrm{pH}$, high porosity characterized by high aeration space and low water retention besides the maintenance of the structure during cultivation (KÄMPF, 2005). In addition, the use of CRH as a substrate component for seedlings of forest species allows lower cost in rice growing regions, including the use of this material.

However, research is needed to evaluate the ideal proportion for each species, given that different responses are obtained, as in a study by Gasparin et al. (2014) in which the authors recommended the use of a substrate composed of peat and CRH (60 and 40\%, respectively) in the production of seedlings of Cabralea canjerana (Vell.) Mart. in the nursery. Regarding fertilization with CRF, results on its use in the production of nursery seedlings for the Fabaceae family have already been described, as in the study by Brondani et al. (2008), testing different doses of CRF in seedlings of Anadenanthera colubrina (Vell.) Brenan. These authors observed that the doses influenced the $\mathrm{H}$, number of leaves, $\mathrm{SD}$ and the dry matter of the seedlings, obtaining results with lower doses $\left(1.53 \mathrm{~g} \mathrm{~L}^{-1}\right)$, however, produced in the winter period. Gasparin et al. (2015) recommended $9 \mathrm{~g} \mathrm{~L}^{-1}$ (1805-09) of substrate for the production of seedlings of Parapiptadenia rigida (Benth.) Brenan. Dutra et al. (2017) indicated doses between 5.4 and $8.2 \mathrm{~g} \mathrm{dm}^{-3}$ (19-06-10) for the production of Peltophorum dubium (Spreng.) Taub.

The treatments NF, RRF and RRFF presented lower means for all morphological and some physiological variables, a fact that may be associated with nutrient leaching. Insufficient supply of nutrients or of some essential element can result in metabolic disturbances in the plant, diagnosed by deficiency symptoms (TAIZ; ZEIGER, 2009), limiting its growth and development.

Controlled release fertilizers can have an influence mainly by reducing nitrogen loss from the substrate by leaching. Gradual distribution is an alternative to increase fertilization efficiency. According to Silva et al. (2014), the most appropriate strategy in the production of quality seedlings is nutritional management, seeking to reduce fertilizer waste.

The values found for the $\mathrm{F}_{\mathrm{v}} / \mathrm{F}_{\mathrm{m}}$ ratio (Table 4) suggest a photochemical stress condition, since all presented means below what is recommended by Araújo and Deminicis (2009), who describe that, under optimal conditions, this ratio should be close to 0.8. However, studies with seedling of Cordia trichotoma (Vell.) Arrab. ex Steud. (KELLING et al., 2017) and Ilex paraguariensis A. St. Hil. (ZAVISTANOVICZ et al., 2017) indicated means between 0.5 and 0.7 , considered adequate in the nursery. For the physiological attributes there was a similar performance regarding the fertilization for chlorophyll $a$ and $b$. Higher levels (Table 4) in the plants indicate higher photosynthetic efficiency, as higher concentrations are responsible for greater light absorption (TAIZ; ZEIGER, 2009). This result may be related to nutrient supply, especially nitrogen, which is a constituent of the chlorophyll molecule. Nutrients are involved in the photosynthesis process of plants. Plants require larger amounts of Nitrogen, which serves as a constituent in various cell components, such as amino acids, proteins and nucleic acids (TAIZ; ZAIGER, 2009). Phosphorus plays a fundamental role in photosynthesis, sugar metabolism, energy storage and transfer, cell division, promoting initial formation, root development and plant growth (TAIZ; ZAIGER, 2009). According to the same authors, potassium has the functions of stomatal regulation, cell membrane dynamics, osmotic balance, carbohydrate transport, among others. Magnesium is an essential element, as a central atom of the chlorophyll molecule, which is also required for many enzymes involved in phosphate transfer, respiration 
enzyme activation, DNA and RNA synthesis, photosynthesis and maintenance of ribosome integrity and protein synthesis (MAATHUIS, 2009).

The highest mean for carotenoids was in substrate S2 in the fertilization with RRFF (Table 4), which can be explained by Taiz and Zeiger (2009), who described that besides the function of accessory pigments, carotenoids play an essential role in photoprotection, by rapidly dissipating the excited states of chlorophyll via the xanthophyll cycle. Thus, given the low growth of seedlings in this condition, this fact may have occurred.

In this study it was observed that Myrocarpus frondosus adapts well in unsaturated environments that favor its growth and that the carbonated rice husk can be used as the main component for the production of seedlings of this species.

\section{CONCLUSION}

- The carbonated rice husk can be used as a substrate component for the production of seedlings of Myrocarpus frondosus. In addition, controlled release fertilization influences the growth and development of seedlings of this species.

- In the production of seedlings of Myrocarpus frondosus, the use of the commercial Sphagnum peat based substrate and carbonated rice husk (40 and 60\%, respectively) is recommended, associated with $6 \mathrm{~g} \mathrm{~L}^{-1}$ of controlled release fertilizer (18-05-09).

\section{ACKNOWLEDGMENTS}

The authors would like to thank Coordenação de Aperfeiçoamento de Pessoal de Nível Superior (CAPES) for granting scholarship to the first author and to the Conselho Nacional de Desenvolvimento Científico e Tecnológico (CNPq) for the scholarship of productivity in research provided to the second author.

\section{REFERENCES}

ARAÚJO, S. A. C.; DEMINICIS, B. B. Fotoinibição da fotossíntese. Revista Brasileira de Biociências, Porto Alegre, v. 7, n. 4, p. 463-472, 2009.

BRONDANI, G. E.; CASTOLDI SILVA, A. J.; SANTOS REGO, S.; ALMEIDA GRISI, F.; NOGUEIRA, A. C.; WENDLING, I.; ARAUJO, M. A. D. Fertilização de liberação controlada no crescimento inicial de angico-branco. Scientia Agraria, Curitiba, v. 9, n. 2, p. 167-176, 2008.

CARVALHO, P. E. R. Espécies Arbóreas Brasileiras. Brasília: Informação Tecnológica. Colombo, Paraná: EMBRAPA Florestas, 2003, v. 1, 1039 p.

DE BOODT, M.; VERDONCK, O. The physical properties of the substrates in horticulture. Acta Horticulturae, Wageningen, v. 26, p. 37-44, 1972.

DICKSON, A.; LEAF, A. L.; HOSNER, J. F. Quality appraisal of white spruce and white pine seedling stock in nurseries. Forestry Chronicle, v. 36, n. 8, p. 10-13, 1960.

DUTRA, T. R.; MASSAD, M. D.; SARMENTO, M. F. Q.; MATOS, P. S.; de OLIVEIRA, J. C. Fertilizante de liberação lenta no crescimento e qualidade de mudas de canafístula (Peltophorum dubium (Spreng.) Taub.). Floresta, Curitiba, v. 46, n. 4, p. 491-498, 2017.

FERREIRA, D. F. Sisvar: a Guide for its Bootstrap procedures in multiple comparisons. Ciência e Agrotecnologia, Lavras, v. 38, n. 2, p. 109-112, 2014.

GASPARIN, E.; de AVILA, A. L.; ARAUJO, M. M.; CARGNELUTTI FILHO, A.; DORNELES, D. U.; FOLTZ, D. R. F. Influência do substrato e do volume de recipiente na qualidade das mudas de Cabralea canjerana (Vell.) Mart. em viveiro e no campo. Ciência Florestal, Santa Maria, v. 24, n. 3, p. 553-563, 2014.

GASPARIN, E.; ARAUJO, M. M.; SALDANHA, C. W.; TOLFO, C. V. Controlled release fertilizer and container volumes in the production of Parapiptadenia rigida (Benth.) Brenan seedlings. Acta Scientiarum Agronomy, Maringá, v. 37 n. 4, p. 473-481, 2015. 
GONÇALVES, J. L. M. et al. Produção de mudas de espécies nativas: substrato, nutrição, sombreamento e fertilização. In: GONÇALVES, J. L. M.; BENEDETTI, V. (Eds.). Nutrição e fertilização florestal. Piracicaba: IPEF, 2005. p. 309-350.

KÄMPF, A. N. Substrato. In: KÄMPF, A. N. Produção comercial de plantas ornamentais. $2^{a}$ edição, Guaíba: Agrolivros, 2005. p. 45 - 72.

KELLING, M. B.; ARAUJO, M. M.; BENÍTEZ, L. E.; AIMI, S. C.; TURCHETTO, F. Regímenes de riego y dosis de polímero hidroretenedor sobre características morfológicas y fisiológicas de plantas de Cordia trichotoma. Revista Bosque, Chile, v. 38, n. 1, p. 123-131, 2017.

KRATZ, D.; WENDLING, I.; NOGUEIRA, A. C.; DUTRA DE SOUZA, P. V. Substratos renováveis na produção de mudas de Eucalyptus benthamii. Ciência Florestal, Santa Maria, v. 23, n. 4, p. 607-621, 2013.

LICHTENTHALER, H. K. Chlorophylls and carotenoids: pigments of photosynthetic biomembranes. In: PACKER, L.; DOUCE, R. (Eds.). Methods in enzymology. Bad Honnef: Academic, v. 148, p. 350-382, 1987.

MAATHUIS, F. J. Physiological functions of mineral macronutrients. Current in Opinion. Plant Biology, v. 12, n. 3, p. 250-258, 2009.

PODE, R. Potential applications of rice husk ash waste from rice husk biomass power plant. Renew Sustain Energy, Rev, 53, p. 1468-1485, 2016.

SANTI, I. I.; GATTO, D. A.; MACHADO, M. R. G.; DOS SANTOS, P. S. B.; FREITAG, R. A. Chemical Composition, Antioxidant and Antimi-crobial Activity of the Oil and Plant Extract Myrocarpus frondosus Allemão. American Journal of Plant Sciences, Estados Unidos, v. 8, p. 1560-1571, 2017.

SCHMITZ, J. A. K.; SOUZA, P. V. D.; KÄMPF, N. A. Propriedades químicas e físicas de substratos de origem mineral e orgânica para o cultivo de mudas em recipientes. Ciência Rural, Santa Maria, v. 32, n. 6, p. 937-944, 2002.

SILVA, R. B. G. da; SILVA, M. R. da; SIMÕES, D. Substrates and controlled-release fertilizations on the quality of eucalyptus cuttings. Revista Brasileira de Engenharia Agrícola e Ambiental, Campina Grande, v. 18, n. 11, p. 1124-1129, 2014.

TAIZ, L.; ZEIGER, E. Fisiologia vegetal. 4 ed. Porto Alegre: Artmed, 2009. 848 p.

TROPICOS: Missouri Botanical Garden. 2018. Disponível em: < http://www.tropicos.org/Name/20400624. Acesso em: 30 abr. 2018.

ZAVISTANOVICZ, T. C.; ARAUJO, M. M.; AIMI, S. C.; FLORES, R.; BERGHETTI, Á. L.; DEPONTI, G. Morphophysiological responses of Ilex paraguariensis seedlings to different substrates and fertilizations. Revista Brasileira de Engenharia Agrícola e Ambiental, Campina Grande, v. 21, n. 2, p. 111-115, 2017. 